\title{
Carryover effects of potassium supplementation on calcium homeostasis in dairy cows at parturition
}

\author{
M. S. Bhanugopan, W. J. Fulkerson, D. R. Fraser, M. Hyde, and D. M. McNeill ${ }^{1,2,3}$ \\ Faculty of Veterinary Science, University of Sydney, NSW 2570, Australia
}

\section{ABSTRACT}

The purpose of this study was to test whether supplementation with $\mathrm{K}$ improves bone mineral density (BMD) in older cows so that by parturition their bone is better able to mobilize Ca. Twenty-four Holstein Friesian cows (6 mo pregnant, lactating, and in their third or later lactation) were allocated to 2 equal groups and individually fed twice daily a total diet comprising low $\mathrm{K}$ oaten hay plus a pelleted concentrate fortified with or without $\mathrm{K}_{2} \mathrm{CO}_{3}$ to achieve $3.12 \% \mathrm{~K} / \mathrm{kg}$ of $\mathrm{DM}$ in the total diet of the K-supplemented (KS) cows compared with $1.50 \% \mathrm{~K} / \mathrm{kg}$ of DM for the control cows. The cows were fed their respective diets from the beginning of their sixth month of pregnancy until 2 wk before the expected date of parturition. The strategy was to use $\mathrm{K}$ to stimulate a mild increase in extracellular $\mathrm{pH}$ to potentially improve BMD well before parturition, when high $\mathrm{K}$ contents in the diet are considered safe, but cease supplementing in the few weeks prepartum, when high intakes of $\mathrm{K}$ are known to be problematic. The expectation was that the effect of the denser bone would carry through to benefit the cow's plasma $\mathrm{Ca}, \mathrm{P}$, and $\mathrm{Mg}$ status at parturition. Prior to the period of K supplementation, the cows were part of a commercial pasturebased herd, to which they were returned at the end of the supplementation period and treated as 1 group from at least $11 \mathrm{~d}$ prepartum until the end of the study at d 42 of the next lactation. Supplementation with K successfully induced a sustained increase of urinary $\mathrm{pH}$ throughout late lactation and into the dry period, as expected. The KS cows consistently averaged a urine $\mathrm{pH} 0.25 \pm 0.10 \mathrm{U}$ higher than the controls. However, there was no significant effect of $\mathrm{K}$ supplementation on BMD, bone mineral concentrations, plasma osteocalcin, urinary deoxypyridinoline:creatinine plasma $\mathrm{Ca}$, or

\footnotetext{
Received September 6, 2009.

Accepted December 18, 2009.

${ }^{1}$ Corresponding author: d.mcneill@uq.edu.au

${ }^{2}$ Interim address: Tasmanian Institute of Agricultural Research, University of Tasmania, Burnie TAS 3523, Australia.

${ }^{3}$ Current address: School of Veterinary Science, University of Queensland, Gatton QLD 4343, Australia.
}

plasma $\mathrm{P}$ concentrations during or immediately after the cessation of supplementation, nor where there any carryover effects during parturition or by d 42 of lactation. Instead, there was an unexpected decrease in the concentration of $\mathrm{Mg}$ in plasma of the KS cows compared with the control cows that extended from 0.5 to $2.5 \mathrm{~d}$ postpartum. The timing of the decline in plasma $\mathrm{Mg}$ was paralleled by declines in plasma concentrations of 1,25 dihydroxy-vitamin $\mathrm{D}_{3}$ and urinary excretion of $\mathrm{Ca}$ and $\mathrm{Mg}$, whereas urinary excretion of $\mathrm{P}$ increased; all changes were consistent with a hypomagnesemia that could increase the risk of hypocalcemia. These data suggest that, in addition to the well-documented negative effects of $\mathrm{K}$ when fed immediately at parturition, the effects of high dietary $\mathrm{K}$ diets can carry over for at least $11 \mathrm{~d}$ to trigger a mild hypomagnesemia at parturition. Because $\mathrm{K}$ supplementation did not improve BMD prepartum, it was not possible to conclude for or against an ability of denser bone to reduce the risk of hypocalcemia in older cows at parturition.

Key words: bone health, parturition, hypocalcemia, hypomagnesemia

\section{INTRODUCTION}

Diets rich in $\mathrm{K}$ are strongly implicated as a cause of periparturient hypocalcemia in the dairy cow, and the period of greatest risk is in the days immediately prepartum (Goff and Horst, 1997; Lean et al., 2006; Roche and Berry, 2006; DeGaris and Lean, 2008; Goff, 2008). Two hypotheses relate high $\mathrm{K}$ intakes to hypocalcemia at this time. High $\mathrm{K}$ diets can 1 ) slightly alkalinize the extracellular fluid of the cow, which in turn reduces the rate of synthesis of the hormone 1,25 dihydroxyvitamin $\mathrm{D}_{3}\left(\mathbf{1}, 25 \mathrm{OH}\right.$ vit $\left.\mathbf{D}_{3}\right)$ by the kidney, needed to drive the absorption of $\mathrm{Ca}$ from the small intestine, and 2) reduce the rate of absorption of $\mathrm{Mg}$ from the rumen, leading to a hypomagnesemia, which in turn reduces the sensitivity of kidney and bone tissue to parathyroid hormone (PTH). Parathyroid hormone would normally stimulate the synthesis of $1,25 \mathrm{OH}$ vit $\mathrm{D}_{3}$ and, consequently, Ca absorption, as well as promote the mobilization of bone $\mathrm{Ca}$ to improve the flow of $\mathrm{Ca}$ into the blood stream. 
Yet, beyond the immediate prepartum period, the risk of a high $\mathrm{K}$ diet causing metabolic problems is thought to recede and may even be advantageous (Sanchez and Beede, 1996). Studies in humans of osteoporosis indicate that diets rich in $\mathrm{K}$ can improve bone tissue in terms of bone mineral density (BMD) and turnover (Sebastian et al., 1994; New et al., 1997, 2000; Tucker et al., 1999; New, 2000; Jehle et al., 2006). The proposed mechanism linking dietary $\mathrm{K}$ to $\mathrm{BMD}$ is that higher $\mathrm{K}$ diets can lead to a mild increase, within physiological limits, in the $\mathrm{pH}$ and alkalinity of extracellular fluid, which in turn could improve BMD (McNeill et al., 2002). Just as the DCAD literature argues that acidifying the diet stimulates the mobilization of bone mineral (Goff, 2006, 2008; DeGaris and Lean, 2008), alkalinizing the diet could stimulate bone mineral accretion. Jehle et al. (2006) have recently confirmed this in osteopenic women supplemented with an alkalinizing (potassium citrate) compared with a nonalkalinizing (KCl) form of $\mathrm{K}$ over a 12-mo period.

High $\mathrm{K}$ diets that successfully alkalinize metabolism could similarly improve BMD in dairy cows. That is, the increased turnover of bone $\mathrm{Ca}, \mathrm{P}$, or $\mathrm{Mg}$ to be expected from denser bones, if coinciding with parturition, could improve Ca homeostasis at that critical time. Studies in both cattle and sheep indicate dramatic challenges to BMD from one parturition to the next, as reviewed by McNeill et al. (2002). Bone Ca reserves can fluctuate by as much as 10 to $15 \%$, falling throughout early lactation and replenishing in late lactation, and likely result in a general declining trend in BMD over the lifetime of the cow (Kronfeld et al., 1976; Braithwaite, 1983; Gibb et al., 1992). Such reports, while highlighting the natural process of bone loss in early lactation, also highlight the need to provide a diet that promotes the repletion of bone tissue in late lactation and into the dry period.

To investigate the potential advantages of high $\mathrm{K}$ diets, we tested the hypothesis that an alkalinizing supplement, $\mathrm{K}_{2} \mathrm{CO}_{3}$, fed throughout late lactation and into the dry period increases BMD and the capacity of the cow to maintain calcium homeostasis at parturition. Care was taken to cease the addition of $\mathrm{K}_{2} \mathrm{CO}_{3}$ by $14 \mathrm{~d}$ prepartum to remove the risk of any immediate negative effects of $\mathrm{K}$ on $\mathrm{Ca}$ homeostasis at parturition.

\section{MATERIALS AND METHODS}

\section{Experimental Animals, Feeding, and Management}

Two groups of cows were matched for number of days pregnant, number of lactations, milk yield of previous lactation, and liveweight in their sixth month $(140 \mathrm{~d}$ before their expected date of parturition) of their third or later pregnancy, and randomly allocated into either a control or a K-supplemented (KS) group of 11 animals each. The study was conducted in a year-round calving herd at the University of Sydney's Mayfarm and Corstorphine research dairies in Camden, New South Wales, Australia $\left(150^{\circ} 39^{\prime} \mathrm{E}, 34^{\circ} 3^{\prime} \mathrm{S}\right)$. The cows were assembled in 3 batches from July 2003 to January 2004, paired on their predicted date of parturition, and allocated to either group randomly. Final means for the control and KS groups, respectively, at randomization were as follows: number of days pregnant $=152 \pm 3$ and $157 \pm 5 \mathrm{~d}$; number of lactations $=5.0 \pm 0.5$ and $5.0 \pm 0.5$; average milk yield of previous lactation $=$ $24.6 \pm 3.4$ and $21.5 \pm 2.1 \mathrm{~L}$ of milk/d; liveweight $=608$ \pm 25 and $574 \pm 11 \mathrm{~kg}$.

The cows were individually fed a diet of oaten hay plus pelleted concentrate fortified with or without $\mathrm{K}$, as $\mathrm{K}_{2} \mathrm{CO}_{3}$, from $\mathrm{d}-140$ until $14 \mathrm{~d}$ before the expected date of parturition. The level of $\mathrm{K}$ added was designed to reflect that seen in quality pasture. From $14 \mathrm{~d}$ prepartum, all cows were moved into a commercial herd where they were offered a hay and concentrate diet until parturition. After parturition, they were offered a pasture-based diet supplemented with a pelleted concentrate until the study ended at $42 \mathrm{~d}$ postpartum to test for carryover effects on milk production.

From $\mathrm{d}-140$ to $\mathrm{d}-14$, the cows were kept in a 0.5-ha bare paddock adjacent to the milking shed with constant access to full shade and water. They were walked less than $50 \mathrm{~m}$, twice daily following milking, to be fed individually in head bales in 2 equal portions per day (at 0830 and $1630 \mathrm{~h}$ ) a combination of a low $\mathrm{K}$ $(1.7 \% \mathrm{DM})$ long oaten hay and a pelleted concentrate (George Weston Foods Ltd., Chatswood, New South Wales, Australia) with or without added $\mathrm{K}$ in the form of feed grade $\mathrm{K}_{2} \mathrm{CO}_{3}$. Control cows received the basal pellets with a $\mathrm{K}$ concentration of $1.3 \% \mathrm{DM}$ compared with the KS cows, where the $\mathrm{K}$ was added to lift the concentration in the pellets to $4.2 \% \mathrm{DM}$, resulting in dietary concentrations of $\mathrm{K}$ for the entire diets of $3.12 \%$ and 1.50 to $1.57 \%$ for the KS and control cows, respectively (Table 1). From 140 to $70 \mathrm{~d}$ before their expected date of parturition, all cows were offered 9.0 $\mathrm{kg}$ of DM of oaten hay and $9.0 \mathrm{~kg}$ of DM of pellets per day. After lactation ceased, all were fed $8 \mathrm{~kg}$ of DM of oaten hay and $4 \mathrm{~kg}$ of DM of pellets per day until 14 $\mathrm{d}$ before their expected date of parturition; this timing proved to be, in relation to actual date of parturition (mean $\pm \mathrm{SE}), 11.7 \pm 1.6 \mathrm{~d}$ for the control cows and $11.6 \pm 1.4 \mathrm{~d}$ for the KS cows. During late lactation approximately $500 \mathrm{~g} / \mathrm{d}$ of $\mathrm{K}_{2} \mathrm{CO}_{3}$ was mixed with the pelleted portion of the KS diet; this was reduced to 200 $\mathrm{g} / \mathrm{d}$ for the nonlactating period. The $\mathrm{K}_{2} \mathrm{CO}_{3}$ was mixed with the KS pellets immediately before each feeding by dissolving it in $200 \mathrm{~mL}$ of water and stirring it with 
Table 1. Composition of the experimental diets for the periods of $\mathrm{K}$ supplementation (DM basis) ${ }^{1}$

\begin{tabular}{|c|c|c|c|c|}
\hline \multirow[b]{2}{*}{ Item } & \multicolumn{2}{|c|}{ Late lactation } & \multicolumn{2}{|c|}{ Early dry period } \\
\hline & Control & KS & Control & KS \\
\hline \multicolumn{5}{|l|}{ Component (g/kg) } \\
\hline Oaten hay & 500 & 486 & 667 & 656 \\
\hline Pellets & 500 & 486 & 333 & 328 \\
\hline $\mathrm{K}_{2} \mathrm{CO}_{3}$ & 0 & 27 & 0 & 16 \\
\hline \multicolumn{5}{|l|}{ Analysis (\% unless noted) } \\
\hline $\mathrm{CP}$ & 13.9 & 13.9 & 11.7 & 11.7 \\
\hline $\mathrm{ADF}$ & 19.1 & 19.1 & 22.7 & 22.4 \\
\hline NDF & 36.9 & 37.0 & 43.2 & 42.8 \\
\hline $\mathrm{NFC}$ & 11.6 & 11.7 & 17.4 & 17.4 \\
\hline Total digestible nutrient & 70.6 & 71.0 & 69.9 & 70.0 \\
\hline $\mathrm{ME}(\mathrm{MJ})$ & 10.8 & 10.8 & 10.6 & 10.6 \\
\hline $\mathrm{Ca}$ & 0.92 & 0.90 & 1.02 & 1.00 \\
\hline $\mathrm{P}$ & 0.44 & 0.42 & 0.36 & 0.35 \\
\hline $\mathrm{Mg}$ & 0.41 & 0.42 & 0.41 & 0.45 \\
\hline $\mathrm{K}$ & 1.50 & 3.12 & 1.57 & 3.12 \\
\hline $\mathrm{Na}$ & 0.23 & 0.21 & 0.16 & 0.18 \\
\hline $\mathrm{Cl}$ & 0.52 & 0.49 & 0.61 & 0.59 \\
\hline $\mathrm{S}$ & 0.23 & 0.20 & 0.17 & 0.18 \\
\hline $\mathrm{DCAD}^{2}(\mathrm{mEq} / 100 \mathrm{~g})$ & +19 & +62 & +19 & +60 \\
\hline
\end{tabular}

the pellets until absorbed. The hay and pellets (mixed or not mixed with $\mathrm{K}_{2} \mathrm{CO}_{3}$ ) were weighed for each cow into individual bins on the previous day for feeding for the next day.

At $14 \mathrm{~d}$ before their expected date of parturition, all cows were transported $3 \mathrm{~km}$ to the University of Sydney's Corstorphine commercial dairy, where they were combined with the commercial herd of dry cows and offered, as a group, $1.5 \mathrm{~kg}$ of DM of proprietary pellets per day (George Weston Foods Ltd.) and oaten hay ad libitum (Table 1). Actual intakes of the pellets and hay per group or individual cow were not measured from this point onwards because it was considered that the period of treatment to manipulate bone tissue had ceased and that the cows were now into the period of carryover, during which the intention was to mimic commercial conditions for a pasture-based system.

Following parturition, the cows entered the commercial milking herd of approximately 250 cows, which were grazed on a predominately kikuyu (Pennisetum clandestinum) pasture offered ad libitum and supplemented with approximately $6 \mathrm{~kg}$ of DM of corn silage [analysis on DM basis: CP, $14.2 \%$; ADF, $40.3 \%$; NDF, $63.1 \%$; NFC, $14.2 \%$; total digestible nutrient, $51 \%$; ME, $8.9 \mathrm{MJ} / \mathrm{kg}\left(\mathrm{NE}_{\mathrm{L}}=1.12 \mathrm{Mcal} / \mathrm{kg}\right)$; Ca, $0.67 \% ; \mathrm{P}, 0.34 \%$; $\mathrm{Mg}, 0.49 \%$;, $2.34 \%$; $\mathrm{Na}, 0.65 \%$; and $\mathrm{Cl}, 1.84 \%]$ and 6 $\mathrm{kg}$ of DM of pellets/cow per day. The pellets were from the same batch as those fed from $\mathrm{d}-14$ to parturition and so were considered to have a similar compositional value (presented previously), and were fed at the time of milking in 2 equal portions per day. The corn silage was offered on a feed pad between the morning and afternoon milking.

\section{Sampling}

Prior to $\mathrm{d}-14$, the oaten hay was sampled 3 times per week and the pellets, with or without the added $\mathrm{K}_{2} \mathrm{CO}_{3}$, were sampled weekly. Feed samples were combined on monthly basis, dried at $60^{\circ} \mathrm{C}$ for $48 \mathrm{~h}$, ground through a $0.5-\mathrm{mm}$ sieve, and sent for wet chemistry proximate and mineral analysis to Dairy One Forage Laboratory (Ithaca, NY).

Pasture samples were not taken during the period from parturition to d 42 of lactation; it was considered that an approximation of the nutritional profile of the study was all that was needed because the methodology was to impose $\mathrm{K}$ treatment before $\mathrm{d}-14$ and then treat all cows similarly thereafter. A typical nutritive profile of the kikuyu pasture that the cows were grazing can be derived from the pasture study of Fulkerson et al. (2007), conducted at the same time on a site adjacent to the paddocks grazed and on the same soil type [analysis on DM basis: CP, 25.3\%; ADF, 25.9\%; NDF, $50.3 \%$, $\mathrm{ME}$, and $9.9 \mathrm{MJ} / \mathrm{kg}\left(\mathrm{NE}_{\mathrm{L}}=1.52 \mathrm{Mcal} / \mathrm{kg}\right)$. A typical mineral profile for kikuyu is Ca, $0.30 \%$;, $0.42 \%$;g, $0.28 \%$; K, 3.88\%; Na, 0.10\%; and $\mathrm{Cl}, 1.59 \%$ (McNeill et al., 2002).

Blood and urine samples were taken immediately before the initiation of $\mathrm{K}$ supplementation at $140 \mathrm{~d}$ 
before the expected date of parturition, and thereafter weekly, between 0800 and $0900 \mathrm{~h}$, during the morning feeding until $14 \mathrm{~d}$ prior, and then within 2 to $6 \mathrm{~h}$ after parturition, $12 \mathrm{~h}$ after that, and at 2, 2.5, and $42 \mathrm{~d}$ postpartum. Other than the samples on the day of parturition, all blood samples were taken immediately after the morning milking or before the morning feed, chilled and centrifuged at 1,700 $\times g$ for $10 \mathrm{~min}$ within 30 min of sampling, and frozen at $-20^{\circ} \mathrm{C}$ for later analysis. Five-milliliter subsamples of urine were taken immediately at sampling into an ice bath and frozen at $-20^{\circ} \mathrm{C}$ for mineral and creatinine analysis.

Bone biopsy samples were collected on 3 occasions: from the thirteenth rib on the right side immediately before the initiation of the treatment, from the thirteenth rib on the left side at $14 \mathrm{~d}$ before the expected date of parturition, and from the twelfth rib on the right side at 42 postpartum. The cows were restrained in a cattle crush and sedated with Dormosedan (detomidine $\mathrm{HCl}, 10 \mathrm{mg} / \mathrm{mL}$; Pfizer Animal Health, New York, NY) at the dose rate of $0.1 \mathrm{~mL}$ i.v. $/ 100 \mathrm{~kg}$ of BW. An area (approximately $20 \times 20 \mathrm{~cm}$ ) approximately halfway along and centered over the twelfth rib was clipped and scrubbed for surgery. Twenty-five to $30 \mathrm{~mL}$ of local anesthetic (lignocaine $\mathrm{HCl}, 20 \mathrm{mg} / \mathrm{mL}$; Troy Laboratories (Australia) Pty. Ltd., New South Wales, Australia) was applied subcutaneously in multiple injections along the lines of the anterior and dorsal borders of the clipped area to form an inverted L nerve block for the site of incision at the center of the clipped area. A unicortical biopsy was taken using a 14-mm trephine by boring through the lateral cortex and extending into the medullary cavity of the rib until the resistance of the medial cortex was felt, the trephine was withdrawn, and the core was prised from the rib using blunt surgical scissors. A second biopsy sample was taken about 1 to 1.5 $\mathrm{cm}$ dorsal to the first biopsy site. One of each pair of biopsy cores was fixed in 10\% formalin $(\mathrm{pH} 7)$ and the other was fixed in $80 \%$ alcohol for subsequent measurement of BMD and composition (Ca, $\mathrm{P}$, and $\mathrm{Mg}$ ).

\section{Measurements}

Liveweight was measured weekly throughout the experimental period on the first day of each week and immediately before the morning feeding at approximately $0830 \mathrm{~h}$. Body condition scores were measured using a 1 - to 5 -point scale $(1=$ poor to $5=$ good $)$ at the start of the experiment, $14 \mathrm{~d}$ before parturition, immediately after parturition, and $42 \mathrm{~d}$ after parturition (Edmonson et al., 1989).

Urine $\mathrm{pH}$ was measured immediately after sampling using a handheld electronic $\mathrm{pH}$ meter $(\mathrm{pH}-\mathrm{mV}$-Temp Meter, model WP-80, TPS Pty Ltd., Brisbane, Aus- tralia) and used to indicate the potential for changes in acid-base balance of the cows throughout the study (Horst et al., 1997; Goff, 2000; Oetzel, 2000; Seifi et al., 2004).

Concentrations of $\mathrm{Ca}, \mathrm{P}, \mathrm{Mg}$, and $\mathrm{K}$ in plasma and urine were analyzed by inductively coupled plasma emission spectrophotometry. Because the total 24-h urine output could not be measured, the ratio of mineral to creatinine concentration was used as an index of excretion (Asai et al., 2005).

Plasma was assayed for the concentration of $1,25 \mathrm{OH}$ vit $\mathrm{D}_{3}$ (radioimmunoassay kit IDAA-54F2, IDS Laboratories, Abacus Diagnostics, Brisbane, Australia) and the biochemical marker for bone formation, osteocalcin (osteocalcin enzyme immunoassay kit, Nichols Advantage, Nichols Diagnostics, San Juan Capistrano, CA). The monoclonal antiosteocalcin antibody used in the osteocalcin kit was raised against bovine osteocalcin.

Urine was assayed for the concentration of the marker for bone resorption deoxypyridinoline (DPD; pyrilinks-D immunoassay kit, Immulite, Diagnostics Products Corp., Los Angeles, CA) using an Immulite 2000 analyzer; as for the urinary minerals, the ratio of DPD to creatinine concentration was used as an index of excretion.

Bone mineral density in the rib biopsies was measured using a peripheral quantitative computed tomography scanner (Picker International, Cleveland, OH). The biopsies from all sampling times for all cows were scanned in one continuous run. The samples were scanned perpendicularly to the lateral cortex once every $2 \mathrm{~mm}$ such that 5 measures were taken for each biopsy and then averaged for a final BMD per biopsy.

The mineral composition of the bone biopsies was measured after drying to a constant weight at $100^{\circ} \mathrm{C}$ and then grinding to a fine powder with a mortar and pestle. Approximately $100 \mathrm{mg}$ of each homogenized sample was weighed and ashed in a muffle furnace at $550^{\circ} \mathrm{C}$ for $8 \mathrm{~h}$. The ash was then dissolved into concentrated hydrochloric acid, made up to $100 \mathrm{~mL}$ using nanopore deionized water in volumetric flasks, and sent to the Department of Chemical Engineering, University of Sydney, Australia, for analysis by inductively coupled plasma emission spectrophotometry for the concentrations of $\mathrm{Ca}, \mathrm{P}$, and $\mathrm{Mg}$.

The feeding, management, surgical procedures and sampling regimens used on the animals in this experiment were approved by the Animal Ethics Committee, University of Sydney.

\section{Calculations and Statistical Analysis}

The plasma, urine, and bone measurement, liveweight, and condition score data across the entire trial 


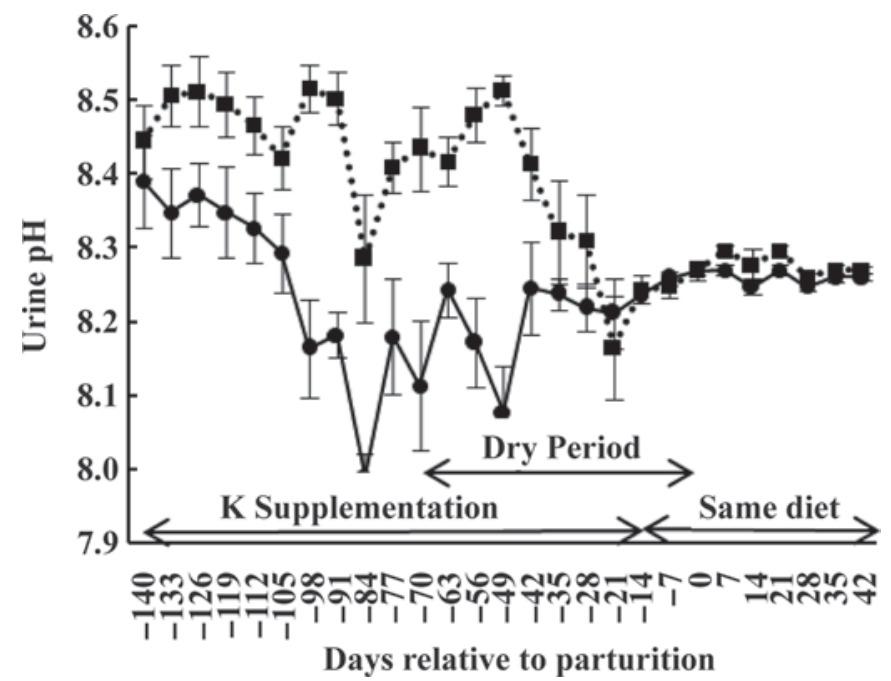

Figure 1. Mean urine pH values of the cows in the control $(\bullet)$ and K-supplemented (ם) groups from $140 \mathrm{~d}$ before the expected date of parturition until $42 \mathrm{~d}$ postpartum (SEM is shown as vertical bars).

were analyzed by repeated measures ANOVA using Genstat (v. 8.0, VSN International, Hemel Hempstead, UK). Both the main effects (treatment, time) and the interaction effects (treatment $\times$ time) were examined. When the ANOVA suggested a significant treatment or time effect, means were compared with Fischer's least significant difference test. Daily liveweight and condition score changes were determined using the generalized linear regression component of Genstat for periods $\mathrm{d}-140$ to $-70, \mathrm{~d}-70$ to 0 , d 0 to 2.5 , and $\mathrm{d} 2.5$ to 42 , with $\mathrm{d} 0$ being the expected date of parturition.

\section{RESULTS}

Throughout the period of $\mathrm{K}$ supplementation, feed refusals were minor $(<1 \%)$ and therefore not recorded. Consequently, the daily DMI of the KS cows, not including the weight of the added $\mathrm{K}_{2} \mathrm{CO}_{3}$, matched that of the control cows until supplementation ceased. Between d -140 and -14 , DMI was $18.0 \mathrm{~kg} / \mathrm{d}$ for the control cows plus $0.50 \mathrm{~kg} / \mathrm{d}$ of $\mathrm{K}_{2} \mathrm{CO}_{3}$ to equal $18.5 \mathrm{~kg}$ of $\mathrm{DM} / \mathrm{d}$ for the KS cows. Between $\mathrm{d}-70$ and -14 , DMI was 12.0 $\mathrm{kg} / \mathrm{d}$ for the control cows plus $0.20 \mathrm{~kg} / \mathrm{d}$ of $\mathrm{K}_{2} \mathrm{CO}_{3}$ to equal $12.2 \mathrm{~kg}$ of DM/d for the KS cows. Compared with the control cows, the KS cows consumed 0.31 and 0.19 $\mathrm{kg}$ more $\mathrm{K} /$ cow per day for periods $\mathrm{d}-140$ to -70 and d -70 to -14 , respectively.

Compared with the targeted $14 \mathrm{~d}$ prepartum, the mean actual number of days prepartum that supplementation ceased was $11.7 \mathrm{~d}$ for the control cows and $11.6 \mathrm{~d}$ for the KS cows [standard error of the difference $($ SED $)=1.09 \mathrm{~d} ; P=0.641]$.
Table 2. Liveweight and BCS means for the cows in the control (no K supplementation) versus K-supplemented (KS) groups relative to the expected date of parturition ${ }^{1}$

\begin{tabular}{|c|c|c|c|c|}
\hline \multirow[b]{2}{*}{ Item } & \multicolumn{2}{|c|}{ Treatment } & \multirow[b]{2}{*}{$\mathrm{SED}^{2}$} & \multirow[b]{2}{*}{$P$-value } \\
\hline & Control & KS & & \\
\hline \multicolumn{5}{|c|}{ Liveweight (kg) } \\
\hline $\mathrm{d}-140$ & 611.8 & 589.0 & 30.36 & 0.470 \\
\hline $\mathrm{d}-70$ & 671.6 & 646.1 & 32.56 & 0.443 \\
\hline $\mathrm{d}-14$ & 735.7 & 704.8 & 29.53 & 0.308 \\
\hline d 0 & 660.2 & 618.6 & 29.82 & 0.179 \\
\hline d 7 & 631.6 & 584.6 & 25.78 & 0.084 \\
\hline d 42 & 584.8 & 544.6 & 27.37 & 0.158 \\
\hline \multicolumn{5}{|l|}{$\mathrm{BCS}^{3}(\mathrm{U})$} \\
\hline $\mathrm{d}-140$ & 3.0 & 2.7 & 0.19 & 0.246 \\
\hline $\mathrm{d}-70$ & $\mathrm{NA}^{4}$ & NA & NA & NA \\
\hline $\mathrm{d}-14$ & 3.9 & 3.8 & 0.14 & 0.439 \\
\hline d 0 & 3.2 & 3.2 & 0.260 & 0.900 \\
\hline d 7 & NA & NA & NA & NA \\
\hline d 42 & 2.0 & 1.8 & 0.14 & 0.203 \\
\hline
\end{tabular}

${ }^{1}$ Period of $\mathrm{K}$ supplementation for the KS cows was from $\mathrm{d}-140$ to -14 .

${ }^{2}$ Standard error of the difference.

${ }^{3}$ On a scale from 1 (poor) to 5 (good).

${ }^{4}$ Not measured at this time.

Throughout the period of K supplementation, the KS cows consistently averaged a urine $\mathrm{pH} 0.25 \mathrm{U}$ higher than that of the control cows $(\mathrm{d}-140$ to -14 : control $=8.23 \mathrm{U}, \mathrm{KS}=8.48 \mathrm{U}$; SED $=0.034 \mathrm{pH}$ units; $P<$ 0.001 ; Figure 1). Prior to the start of supplementation, the urine $\mathrm{pH}$ of all cows averaged $8.36 \pm 0.04 \mathrm{U}$ and decreased erratically until the end of the supplementation period, when both groups converged to average $8.21 \pm$ $0.03 \mathrm{U}$ by $14 \mathrm{~d}$ before the expected date of parturition $(\mathrm{d}-14$ : control $=8.23 \mathrm{U}, \mathrm{KS}=8.24 \mathrm{U} ; \mathrm{SED}=0.023$ $\mathrm{pH}$ units; $P=0.773)$. At the beginning and end of the supplementation period, the treatment groups diverged (control) or converged (KS) within a week of the change in the DCAD of their diets. Thereafter, for the last 14 $\mathrm{d}$ of the dry period and the first $42 \mathrm{~d}$ of lactation, the urine $\mathrm{pH}$ of the treatment groups remained similar and steady, staying between 8.2 and $8.3 \mathrm{U}$.

Cows in both treatment groups gained liveweight and condition score steadily and similarly over the period of $\mathrm{K}$ supplementation and until parturition $(P>0.05$; Tables 2 and 3). Over this period, the liveweight (mean $\pm \mathrm{SE}$ ) of all cows increased from an average of $581 \pm$ $23 \mathrm{~kg}$ at $-140 \mathrm{~d}$ to $700 \pm 20 \mathrm{~kg}$ at parturition. Mean BCS of all cows were 2.8, 3.8, and $3.2 \mathrm{U}$ at $-140 \mathrm{~d}$, -14 , and parturition, respectively. From parturition, mean liveweights and body condition scores of all cows declined by 79 and $59 \%$, respectively, to reach a mean of $556 \mathrm{~kg}$ and $1.9 \mathrm{U}$ by d 42 of lactation.

Supplementation with K had no effect on subsequent milk production (mean yield for the period d 0 to 42 : control $=33.4 \mathrm{~L}, \mathrm{KS}=34.3 \mathrm{~L} ; \mathrm{SED}=1.76 ; P=$ 
Table 3. Rate of change in liveweight and BCS for the cows in the control (no K supplementation) versus K-supplemented (KS) groups for key periods relative to the expected date of parturition ${ }^{1}$

\begin{tabular}{|c|c|c|c|c|}
\hline \multirow[b]{2}{*}{ Item } & \multicolumn{2}{|c|}{ Treatment } & \multirow[b]{2}{*}{$\mathrm{SED}^{2}$} & \multirow[b]{2}{*}{$P$-value } \\
\hline & Control & KS & & \\
\hline \multicolumn{5}{|l|}{ Liveweight change $(\mathrm{kg} / \mathrm{d})$} \\
\hline $\mathrm{d}-140$ to -70 & 0.81 & 1.08 & 0.158 & 0.109 \\
\hline $\mathrm{d}-70$ to -14 & 1.14 & 1.05 & 0.141 & 0.502 \\
\hline $\mathrm{d}-14$ to 0 & -5.40 & -5.50 & 0.595 & 0.226 \\
\hline d 0 to $2.5^{3}$ & -2.08 & -2.46 & 0.813 & 0.639 \\
\hline d 2.5 to 42 & -1.34 & -1.14 & 0.527 & 0.716 \\
\hline \multicolumn{5}{|l|}{ BCS change $^{4}$ (scores/d) } \\
\hline $\mathrm{d}-140$ to -70 & 0.0074 & 0.0082 & 0.00065 & 0.245 \\
\hline $\mathrm{d}-70$ to -14 & 0.013 & 0.015 & 0.00116 & 0.452 \\
\hline $\mathrm{d}-14$ to 0 & -0.0464 & -0.0407 & 0.00408 & 0.656 \\
\hline d 0 to $2.5^{3}$ & -0.0039 & -0.0046 & 0.00011 & 0.240 \\
\hline d 2.5 to 42 & -0.0290 & -0.0324 & 0.00541 & 0.321 \\
\hline
\end{tabular}

${ }^{1}$ Periods of K supplementation for the KS cows were from d -140 to -70 (late lactation) and $\mathrm{d}-70$ to -14 (early dry).

${ }^{2}$ Standard error of the difference.

${ }^{3}$ Day 2.5 values were estimated from d 0 and 7 measures of liveweight and BCS.

${ }^{4}$ On a scale from 1 (poor) to 5 (good).

0.719 ), fat percentage (control $=4.5 ; \mathrm{KS}=4.7 ; \mathrm{SED}$ $=0.36 ; P=0.891)$, or protein percentage $($ control $=$ $3.2, \mathrm{KS}=3.3 ; \mathrm{SED}=0.14 ; P=0.911)$. No incidence of milk fever or any other health issues were encountered at parturition or any other stage of the experiment.

Measures of BMD, bone mineral concentrations, and bone turnover were unaffected by $\mathrm{K}$ supplementation $(P>0.05$; Table 4 and 5$)$. However, all showed pat-

Table 4. Bone mineral density and concentration means for biopsy samples taken from the 12th or 13th ribs of the cows in the control (no K supplementation) versus $\mathrm{K}$-supplemented (KS) groups relative to the expected date of parturition ${ }^{1}$

\begin{tabular}{|c|c|c|c|c|}
\hline \multirow[b]{2}{*}{ Item } & \multicolumn{2}{|c|}{ Treatment } & \multirow[b]{2}{*}{$\mathrm{SED}^{2}$} & \multirow[b]{2}{*}{$P$-value } \\
\hline & Control & $\mathrm{KS}$ & & \\
\hline \multicolumn{5}{|c|}{ Bone mineral density $\left(\mathrm{g} / \mathrm{cm}^{3}\right)$} \\
\hline $\mathrm{d}-140$ & 1.68 & 1.71 & 0.137 & 0.834 \\
\hline $\mathrm{d}-14$ & 1.90 & 1.91 & 0.098 & 0.916 \\
\hline d 42 & 1.98 & 2.00 & 0.109 & 0.815 \\
\hline \multicolumn{5}{|c|}{ Bone $\mathrm{Ca}(\mathrm{mmol} / \mathrm{g})$} \\
\hline $\mathrm{d}-140$ & 3.68 & 3.58 & 0.402 & 0.133 \\
\hline $\mathrm{d}-14$ & 3.65 & 3.84 & 0.363 & 0.130 \\
\hline d 42 & 4.14 & 4.51 & 0.258 & 0.160 \\
\hline \multicolumn{5}{|c|}{ Bone P $(\mathrm{mmol} / \mathrm{g})$} \\
\hline $\mathrm{d}-140$ & 1.23 & 1.21 & 0.102 & 0.110 \\
\hline $\mathrm{d}-14$ & 1.32 & 1.35 & 0.088 & 0.120 \\
\hline d 42 & 1.58 & 1.31 & 0.080 & 0.130 \\
\hline \multicolumn{5}{|c|}{ Bone $\mathrm{Mr}(\mathrm{mmol} / \mathrm{g})$} \\
\hline $\mathrm{d}-140$ & 0.10 & 0.11 & 0.009 & 0.165 \\
\hline $\mathrm{d}-14$ & 0.09 & 0.09 & 0.003 & 0.301 \\
\hline d 42 & 0.11 & 0.11 & 0.007 & 0.380 \\
\hline
\end{tabular}

${ }^{1}$ Period of $\mathrm{K}$ supplementation for the KS cows was from d -140 to -14 .

${ }^{2}$ Standard error of the difference. terns of change over time. The density of bone in the rib biopsies increased by $12 \%$ from $140 \mathrm{~d}$ to $14 \mathrm{~d}$ before the expected date of parturition $(\mathrm{d}-140=1.70, \mathrm{~d}-14$ $\left.=1.91 ; \mathrm{SED}=0.118 \mathrm{~g} / \mathrm{cm}^{3} ; P=0.002\right)$, but there was no detectable change thereafter $(\mathrm{d}-14=1.91$, $\mathrm{d}$ $42=1.99 ;$ SED $=0.056 \mathrm{~g} / \mathrm{cm}^{3} ; P=0.776$; Table 4$)$. Concentrations of $\mathrm{Ca}, \mathrm{P}$, and $\mathrm{Mg}$ in the rib biopsies increased by 19,19 , and $8 \%$, respectively, between 140 $\mathrm{d}$ before the expected date of parturition and $42 \mathrm{~d}$ after $(\mathrm{Ca}: \mathrm{d}-140=3.64, \mathrm{~d} 42=4.33, \mathrm{SED}=0.115 \mathrm{mmol} / \mathrm{g}$, $P=0.002 ; \mathrm{P}: \mathrm{d}-140=1.22, \mathrm{~d} 42=1.45$, SED $=$ $0.036 \mathrm{mmol} / \mathrm{g}, P<0.001 ; \mathrm{Mg}: \mathrm{d}-140=0.10, \mathrm{~d} 42=$ $0.11, \mathrm{SED}=0.003 \mathrm{mmol} / \mathrm{g}, P=0.002$; Table 4$).$ Both plasma osteocalcin and urinary deoxypyridinoline excretion ratios declined as the cow approached parturition (Table 5). The decline was particularly precipitous for osteocalcin for the $14 \mathrm{~d}$ to expected parturition and was lowest on the day of parturition. Both osteocalcin and deoxypyridinoline measures increased at similar rates thereafter. By 42 d after parturition, plasma osteocalcin had returned to levels similar to those recorded at $140 \mathrm{~d}$ before expected parturition. Over the same timeframe, deoxypyridinoline excretion ratio finished $72 \%$ higher (urinary deoxypyridinoline:creatinine ratio: $\mathrm{d}-140=$ $10.72 ;$ d $42=18.40 ;$ SED $=1.812 ; P<0.001)$.

Of the plasma minerals, only $\mathrm{Mg}$ was affected by $\mathrm{K}$ supplementation, and the effect was delayed. A time lag of at least $11 \mathrm{~d}$ occurred between the cessation of $\mathrm{K}$ supplementation prepartum and a sustained depression

Table 5. Mean concentrations of biochemical markers of bone turnover for the cows in the control (no $\mathrm{K}$ supplementation) versus K-supplemented (KS) groups relative to the expected date of parturition $^{1}$

\begin{tabular}{lrrrr}
\hline & \multicolumn{2}{c}{ Treatment } & & \\
\cline { 2 - 3 } & Control & KS & & \\
Item & SED $^{2}$ & $P$-value \\
\hline Plasma osteocalcin $(\mathrm{ng} / \mathrm{mL})$ & & & & \\
d - & 12.20 & 12.00 & 2.734 & 0.960 \\
d - 14 & 9.71 & 9.31 & 1.561 & 0.743 \\
d 0 & 3.27 & 2.34 & 0.526 & 0.094 \\
d 0.5 & 2.31 & 1.68 & 0.290 & 0.060 \\
d 2 & 5.50 & 4.64 & 1.638 & 0.610 \\
d 2.5 & 4.81 & 5.50 & 1.591 & 0.670 \\
d 42 & 10.42 & 10.61 & 1.728 & 0.914 \\
Urinary DPD ${ }^{3}$ :creatinine & & & & \\
d -140 & 10.56 & 10.87 & 1.276 & 0.810 \\
d -14 & 9.88 & 10.10 & 0.836 & 0.785 \\
d 0 & 10.86 & 8.65 & 1.161 & 0.080 \\
d 0.5 & 10.19 & 10.61 & 1.018 & 0.688 \\
d 2 & 13.38 & 13.10 & 1.215 & 0.827 \\
d 2.5 & 14.72 & 14.22 & 3.383 & 0.884 \\
d 42 & 17.02 & 19.78 & 2.564 & 0.296 \\
\hline
\end{tabular}

${ }^{1}$ Period of $\mathrm{K}$ supplementation for the KS cows was from $\mathrm{d}-140$ to -14 .

${ }^{2}$ Standard error of the difference.

${ }^{3}$ Urinary deoxypyridinoline crosslinks. 
Table 6. Mean concentrations of plasma minerals for the cows in the control (no K supplementation) versus K-supplemented (KS) groups relative to the expected date of parturition ${ }^{1}$

\begin{tabular}{|c|c|c|c|c|}
\hline \multirow[b]{2}{*}{ Item } & \multicolumn{2}{|c|}{ Treatment } & \multirow[b]{2}{*}{$\mathrm{SED}^{2}$} & \multirow[b]{2}{*}{$P$-value } \\
\hline & Control & $\mathrm{KS}$ & & \\
\hline \multicolumn{5}{|c|}{$\mathrm{Ca}(\mathrm{mmol} / \mathrm{L})$} \\
\hline $\mathrm{d}-140$ & 2.20 & 2.21 & 0.103 & 0.130 \\
\hline $\mathrm{d}-14$ & 2.11 & 1.97 & 0.102 & 0.072 \\
\hline d 0 & 1.56 & 1.59 & 0.093 & 0.741 \\
\hline d 0.5 & 1.72 & 1.62 & 0.138 & 0.078 \\
\hline d 2 & 1.80 & 1.84 & 0.111 & 0.882 \\
\hline d 2.5 & 1.84 & 1.82 & 0.184 & 0.543 \\
\hline d 42 & 2.08 & 2.01 & 0.136 & 0.522 \\
\hline \multicolumn{5}{|c|}{$\mathrm{P}(\mathrm{mmol} / \mathrm{L})$} \\
\hline $\mathrm{d}-140$ & 1.28 & 1.27 & 0.221 & 0.320 \\
\hline $\mathrm{d}-14$ & 1.18 & 1.17 & 0.106 & 0.920 \\
\hline d 0 & 0.75 & 0.88 & 0.123 & 0.080 \\
\hline d 0.5 & 0.87 & 1.00 & 0.132 & 0.310 \\
\hline d 2 & 1.01 & 0.97 & 0.129 & 0.752 \\
\hline d 2.5 & 1.08 & 0.98 & 0.131 & 0.432 \\
\hline d 42 & 1.28 & 1.33 & 0.113 & 0.530 \\
\hline \multicolumn{5}{|c|}{$\mathrm{Mg}(\mathrm{mmol} / \mathrm{L})$} \\
\hline $\mathrm{d}-140$ & 0.75 & 0.75 & 0.043 & 0.990 \\
\hline $\mathrm{d}-14$ & 0.75 & 0.71 & 0.036 & 0.137 \\
\hline d 0 & 0.86 & 0.82 & 0.062 & 0.551 \\
\hline d 0.5 & 0.88 & 0.69 & 0.075 & 0.021 \\
\hline d 2 & 0.75 & 0.67 & 0.063 & 0.042 \\
\hline $\mathrm{d} 2.5$ & 0.67 & 0.57 & 0.054 & 0.031 \\
\hline d 42 & 0.77 & 0.75 & 0.049 & 0.556 \\
\hline \multicolumn{5}{|c|}{$\mathrm{K}(\mathrm{mmol} / \mathrm{L})$} \\
\hline $\mathrm{d}-140$ & 3.92 & 3.90 & 0.227 & 0.501 \\
\hline $\mathrm{d}-14$ & 3.95 & 3.97 & 0.158 & 0.788 \\
\hline d 0 & 3.86 & 3.85 & 0.220 & 0.975 \\
\hline d 0.5 & 4.04 & 3.93 & 0.149 & 0.467 \\
\hline d 2 & 3.85 & 3.98 & 0.182 & 0.475 \\
\hline $\mathrm{d} 2.5$ & 3.90 & 3.94 & 0.195 & 0.780 \\
\hline d 42 & 3.76 & 3.75 & 0.136 & 0.418 \\
\hline
\end{tabular}

${ }^{1}$ Period of K supplementation for the KS cows was from d -140 to -14 .

${ }^{2}$ Standard error of the difference.

in the plasma $\mathrm{Mg}$ of the $\mathrm{KS}$ cows relative to the control cows that started on the day of parturition (Table 6). The depression was deepest on the day of parturition and lasted for at least the next $2.5 \mathrm{~d}(P<0.05)$. On the day of parturition, the KS cows had concentrations that were $22 \%$ lower than the control cows (control $=$ $0.88, \mathrm{KS}=0.69 ; \mathrm{SED}=0.075 \mathrm{mmol} / \mathrm{L} ; P=0.021)$. None of the KS cows had plasma $\mathrm{Mg}$ concentrations $<0.4 \mathrm{mmol} / \mathrm{L}$, but all the $\mathrm{KS}$ cows had plasma $\mathrm{Mg}$ concentrations within the range of 0.6 to $0.8 \mathrm{mmol} / \mathrm{L}$ $12 \mathrm{~h}$ after parturition; this decreased to a range of 0.55 to $0.65 \mathrm{mmol} / \mathrm{L}$ by $2.5 \mathrm{~d}$ after parturition. For both treatment groups there was a general trend for plasma $\mathrm{Mg}$ concentrations to increase over the $14 \mathrm{~d}$ prepartum, decrease for the 2 to $2.5 \mathrm{~d}$ after parturition, and then increase to prepartum levels by $42 \mathrm{~d}$ postpartum. By contrast, plasma $\mathrm{Ca}$ and $\mathrm{P}$ concentrations declined toward parturition and increased thereafter to reach prepartum levels by $42 \mathrm{~d}$ postpartum (Table 6). Mean
Table 7. Mean urinary excretion of $\mathrm{Ca}, \mathrm{P}, \mathrm{Mg}$, and $\mathrm{K}$ for the cows in the control (no K supplementation) versus K-supplemented (KS) groups relative to the expected date of parturition ${ }^{1}$

\begin{tabular}{|c|c|c|c|c|}
\hline \multirow[b]{2}{*}{ Item } & \multicolumn{2}{|c|}{ Treatment } & \multirow[b]{2}{*}{$\mathrm{SED}^{2}$} & \multirow[b]{2}{*}{$P$-value } \\
\hline & Control & KS & & \\
\hline \multicolumn{5}{|l|}{ Urinary Ca:creatinine } \\
\hline $\begin{array}{l}\mathrm{d}-140 \\
\mathrm{~d}-14\end{array}$ & $\begin{array}{l}0.075 \\
0.077\end{array}$ & $\begin{array}{l}0.075 \\
0.074\end{array}$ & $\begin{array}{l}0.0156 \\
0.0328\end{array}$ & $\begin{array}{l}0.223 \\
0.109\end{array}$ \\
\hline $\begin{array}{l}\mathrm{d}-14 \\
\mathrm{~d} 0\end{array}$ & $\begin{array}{l}0.077 \\
0.082\end{array}$ & $\begin{array}{l}0.074 \\
0.046\end{array}$ & $\begin{array}{l}0.0328 \\
0.0242\end{array}$ & $\begin{array}{l}0.199 \\
0.039\end{array}$ \\
\hline d 0.5 & 0.064 & 0.057 & 0.0140 & 0.629 \\
\hline d 2 & 0.074 & 0.046 & 0.0170 & 0.027 \\
\hline $\mathrm{d} 2.5$ & 0.075 & 0.052 & 0.0211 & 0.035 \\
\hline d 42 & 0.105 & 0.136 & 0.0454 & 0.511 \\
\hline \multicolumn{5}{|l|}{ Urinary P:creatinine } \\
\hline $\mathrm{d}-140$ & 0.037 & 0.038 & 0.0430 & 0.393 \\
\hline $\mathrm{d}-14$ & 0.022 & 0.024 & 0.0068 & 0.408 \\
\hline d 0 & 0.024 & 0.034 & 0.0146 & 0.041 \\
\hline d 0.5 & 0.018 & 0.058 & 0.0267 & 0.017 \\
\hline $\mathrm{d} 2$ & 0.059 & 0.032 & 0.0309 & 0.392 \\
\hline d 2.5 & 0.032 & 0.035 & 0.0242 & 0.877 \\
\hline d 42 & 0.014 & 0.022 & 0.0044 & 0.661 \\
\hline \multicolumn{5}{|l|}{ Urinary Mg:creatinine } \\
\hline $\mathrm{d}-140$ & 1.77 & 1.87 & 0.236 & 0.665 \\
\hline $\mathrm{d}-14$ & 1.51 & 0.74 & 0.219 & 0.029 \\
\hline d 0 & 0.95 & 0.42 & 0.269 & 0.042 \\
\hline d 0.5 & 0.92 & 0.55 & 0.278 & 0.021 \\
\hline d 2 & 0.91 & 0.49 & 0.369 & 0.028 \\
\hline $\mathrm{d} 2.5$ & 0.53 & 0.81 & 0.399 & 0.029 \\
\hline d 42 & 1.78 & 1.86 & 0.734 & 0.661 \\
\hline \multicolumn{5}{|l|}{ Urinary K:creatinine } \\
\hline $\mathrm{d}-140$ & 20.54 & 19.18 & 4.310 & 0.756 \\
\hline $\mathrm{d}-14$ & 21.44 & 37.90 & 6.071 & 0.014 \\
\hline d 0 & 14.88 & 11.59 & 4.476 & 0.472 \\
\hline d 0.5 & 15.15 & 12.44 & 4.014 & 0.508 \\
\hline d 2 & 16.88 & 13.12 & 3.585 & 0.307 \\
\hline d 2.5 & 12.70 & 15.09 & 3.909 & 0.547 \\
\hline $\mathrm{d} 42$ & 17.18 & 17.44 & 3.374 & 0.941 \\
\hline
\end{tabular}

${ }^{1}$ Period of $\mathrm{K}$ supplementation for the KS cows was from $\mathrm{d}-140$ to -14 .

${ }^{2}$ Standard error of the difference.

concentrations of $\mathrm{K}$ in the plasma of both treatment groups remained steady throughout the trial (Table $6)$.

Excretion of $\mathrm{K}$ in the urine increased in the KS group during the period of $\mathrm{K}$ supplementation $(\mathrm{d}-14: P=$ 0.014 ), returned to similar levels as in the control cows by parturition (d $0: P=0.472$ ), and stayed similar thereafter (Table 7). Urinary excretion of $\mathrm{Mg}$ also declined during the period of $\mathrm{K}$ supplementation in the KS cows compared with the control cows $(\mathrm{d}-14: P=$ $0.029)$. However, as for plasma $\mathrm{Mg}$, the depression in urinary $\mathrm{Mg}$ excretion was still apparent at parturition (d 0: $P=0.042)$ and persisted for $2 \mathrm{~d}$ after $(P<0.05)$. A similarly delayed effect of $\mathrm{K}$ supplementation on the urinary excretion of Ca was also apparent, starting at parturition (d 0: $P=0.039$ ) and persisting for $2.5 \mathrm{~d}$.

A delayed effect of $\mathrm{K}$ supplementation on the urinary excretion of $\mathrm{P}$ was also defined (Table 7). Compared with the control cows, $\mathrm{P}$ excretion in the KS cows in- 
Table 8. Mean concentrations (pg/mL) of plasma 1,25 dihydroxyvitamin $\mathrm{D}_{3}$ for the cows in the control (no K supplementation) versus K-supplemented (KS) groups relative to the expected date of parturition $^{1}$

\begin{tabular}{|c|c|c|c|c|}
\hline \multirow{2}{*}{$\begin{array}{l}\text { Plasma } 1,25 \\
\text { dihydroxyvitamin } \mathrm{D}_{3} \\
\text { concentration }(\mathrm{pg} / \mathrm{mL})\end{array}$} & \multicolumn{2}{|c|}{ Treatment } & \multirow[b]{2}{*}{$\mathrm{SED}^{2}$} & \multirow[b]{2}{*}{$P$-value } \\
\hline & Control & $\mathrm{KS}$ & & \\
\hline $\mathrm{d}-140$ & 14.7 & 13.5 & 2.23 & 0.490 \\
\hline d -14 & 20.1 & 19.0 & 3.11 & 0.470 \\
\hline d 0 & 93.1 & 62.5 & 13.90 & 0.027 \\
\hline d 0.5 & 140.9 & 106.9 & 14.25 & 0.031 \\
\hline d 2 & 88.0 & 69.1 & 13.22 & 0.040 \\
\hline d 2.5 & 58.0 & 55.5 & 10.74 & 0.764 \\
\hline d 42 & 30.2 & 29.6 & 2.56 & 0.496 \\
\hline
\end{tabular}

${ }^{1}$ Period of K supplementation for the KS cows was from d -140 to -14 .

${ }^{2}$ Standard error of the difference.

creased to peak on the day of parturition (d 0.5: $P=$ 0.017) and then declined, reaching control levels $2 \mathrm{~d}$ after parturition.

Similarly, a delayed effect of K supplementation was defined on the concentration of $1,25(\mathrm{OH})_{2} \mathrm{D}_{3}$ in the plasma (Table 8). Both treatment groups showed similarly low concentrations before and during the period of $\mathrm{K}$ supplementation, increasing more than 5-fold to peak on the day of parturition. However, concentrations in the control cows peaked $32 \%$ higher than in the KS cows (d 0.5: control $=140.9, \mathrm{KS}=106.9$; SED $=14.25 \mathrm{pg} / \mathrm{mL} ; P=0.031)$ and remained greater for the $2 \mathrm{~d}$ postpartum $(P<0.05)$ before both decreased to prepartum levels by $42 \mathrm{~d}$ postpartum.

\section{DISCUSSION}

The purpose of this study was to investigate the potential for positive effects of a high $\mathrm{K}$ diet through late lactation and into the dry period. The proposed mechanism was that alkalinizing diets promote an improvement in BMD, which allows a greater mobilization of bone mineral at parturition. We successfully alkalinized the urine of the KS cows relative to the controls for 18 wk, up until on average $11 \mathrm{~d}$ prepartum, when supplementation ceased. Yet, no improvement in any of the measures of bone was detected as a result of treatment. Nor was there a beneficial carryover effect on Ca homeostasis at parturition, subsequent milk production, or patterns of liveweight and body condition change. To the contrary, alkalinizing the diet negatively affected Ca homeostasis, a carryover effect possibly mediated by a mild hypomagnesemia that began at parturition.

Potassium supplementation did not improve BMD or turnover. Despite achieving an extended alkalosis abruptly starting and finishing within the 18 -wk period of supplementation, all measures of bone remained un- affected by treatment. As expected, urinary pH stayed higher (the difference averaging $0.25 \mathrm{U}$ ) in the KS cows compared with the control cows for the entire period of supplementation. Consequently, although it was an effective means of alkalinizing metabolism, using a $\mathrm{K}_{2} \mathrm{CO}_{3}$ supplement to promote BMD and turnover cannot be recommended on the basis of the present results. However, a qualification to this should be noted based on the observation that, on average, BMD improved by $12 \%$ for both treatment groups through late lactation and the dry period until $11 \mathrm{~d}$ prepartum. The lack of effect of the K may simply have been a consequence of the control cows already being in a sufficiently mild alkalotic state to promote BMD and turnover. The DCAD for each diet being well into the positive supports this (control $=+19 \mathrm{mEq} / 100 \mathrm{~g}$ of $\mathrm{DM}, \mathrm{KS}=+62$ $\mathrm{mEq} / 100 \mathrm{~g}$ of $\mathrm{DM})$.

A control diet with a DCAD closer to zero could have been more helpful in allowing a more definite conclusion as to the benefits of an alkalosis to bone tissue. However, it proved difficult to find natural ingredients (excluding anionic products) of sufficient quality that were any lower in DCAD than those used.

Nonetheless, our data confirm the general finding of others that cows replenish bone mineral throughout late lactation and into the dry period (Zetterholm, 1978; Holmberg et al., 1985; van Mosel et al., 1990). However, we were surprised to see a tendency for the trend to continue through early lactation. By contrast, others have noted a generalized resorption of bone that may start as early as parturition but increases through early lactation. Several studies have suggested that BMD increases during late lactation and the dry period and then decreases from $90 \mathrm{~d}$ onwards after the onset of lactation (Zetterholm, 1978; Holmberg et al., 1985; van Mosel et al., 1990). Similarly, Liesegang (2003) used peripheral quantitative computed tomography to measure $\mathrm{BMD}$ and bone mineral concentration together with several biochemical markers of bone turnover in live pregnant and lactating sheep and goats and reported a decrease in bone mass during lactation and an increase in bone resorption at the beginning of lactation. Similar to the present study, Beighle (1999) noted an increase in the $\mathrm{Ca}$ and $\mathrm{Mg}$ content of the cortical portion of rib bone biopsies of dairy cows during late gestation, which continued for $30 \mathrm{~d}$ after parturition.

We are unsure why BMD and bone mineral concentration did not decrease from $11 \mathrm{~d}$ prepartum to $42 \mathrm{~d}$ into early lactation. A decrease was expected and was indicated by the bone marker results, but may simply have been too small to detect. Concentrations of the marker for bone formation, plasma osteocalcin, showed an obvious decline relative to the marker for resorption, urinary DPD. The decline started at parturition 
and the difference was still evident $42 \mathrm{~d}$ into lactation. Moreover, the concentrations of both markers were clearly higher $42 \mathrm{~d}$ into lactation; because rate of mineral turnover should positively relate to availability of mineral to extracellular fluid, this was indicative that the importance of bone as a source of mineral may be more important in early lactation than immediately at parturition.

Whereas bone tissue remained unaffected, an intriguing carryover effect of $\mathrm{K}$ supplementation occurred for $\mathrm{Ca}, \mathrm{P}$, and $\mathrm{Mg}$ in plasma and urine. At least $11 \mathrm{~d}$ after supplementation ceased, plasma concentrations of $\mathrm{Mg}$ and urinary excretion rates of $\mathrm{Mg}$ and $\mathrm{Ca}$ were depressed in the KS cows compared with the control cows. Concentrations of $\mathrm{Mg}$ commonly increase immediately after parturition (Goff, 2006). However, in the case of the KS cows, the increase was delayed by at least $1 \mathrm{~d}$ compared with the control cows. The negative effects of supplementation were first detected on the day of parturition and persisted for the next $2 \mathrm{~d}$. Similarly, concentrations of $1,25 \mathrm{OH}$ vit $\mathrm{D}_{3}$ stayed depressed for the same period. By contrast, urinary excretion of $\mathrm{P}$ increased in the KS cows, but only on the day of parturition.

In explaining the carryover effect of $\mathrm{K}$, plasma $\mathrm{Mg}$ could be the mediating link. Several recent metaanalyses list low dietary $\mathrm{Mg}$ as a major risk factor for periparturient hypocalcemia (Enevoldsen, 1993; Charbonneau et al., 2006; Lean et al., 2006; DeGaris and Lean, 2008). The reasoning used to explain this is that $\mathrm{Mg}$ is essential for the functioning of the second messenger system that amplifies the message of PTH, itself induced by a decrease in plasma Ca. Parathyroid hormone, via this second messenger system, stimulates the kidney to synthesize more $1,25 \mathrm{OH}$ vit $\mathrm{D}_{3}$ and hence improve Ca flows into the blood stream (Goff, 2006). Our data are consistent with the above reasoning; the normally observed increase in plasma $\mathrm{Mg}$ at parturition was delayed in the KS cows, presumably leading to a dampening of the PTH message and hence our observed reduction in the concentration of $1,25 \mathrm{OH}$ vit $\mathrm{D}_{3}$ in plasma. An intriguing question here is whether a dampening of the PTH message could stimulate an increased concentration of PTH in the plasma of the KS cows to compensate. Unfortunately, PTH was not measured in the present study. However, it has been reported that PTH stimulates a reduction in rate of excretion of $\mathrm{Ca}$ and $\mathrm{Mg}$ in the urine and increases the excretion of P (Goff, 2006), all of which were responses noted in the KS cows.

If hypomagnesemia is the mediating link, then the solution to reducing the risk of hypocalcemia could be as simple as supplementing the cows with $\mathrm{Mg}$ immediately before and for the few days after parturition. For example, in studies with cows on a predominantly pasture diet in New Zealand, where DCAD levels can easily approach those fed to the KS cows in the present study, Roche (2003) and Roche et al. (2003) observed that about $70 \%$ of the cows were hypomagnesemic on the day of parturition and that supplementation with $\mathrm{Mg}$ alleviated problems of both hypomagnesemia and hypocalcemia.

A further question is how an effect of $\mathrm{K}$ could persist for $11 \mathrm{~d}$ after supplementation ceased. Immediate effects of $\mathrm{K}$ on $\mathrm{Mg}$ metabolism are well documented, but delayed effects are not. It is well accepted that there is an immediate link among high ruminal levels of $\mathrm{K}$, poor ruminal absorption of $\mathrm{Mg}$, and depressed concentrations of $\mathrm{Mg}$ in plasma (Reinhardt et al., 1988; Hungerford, 1990; van Mosel et al., 1991; Leonhard-Marek and Martens, 1996; Ram et al., 1998; Schonewille et al., 1999; Underwood and Suttle, 1999; Goff, 2000). Two mechanisms exist for the transport of $\mathrm{Mg}$ across the rumen wall (Schonewille et al., 1999). The first is driven by the magnitude of the difference in electric charge across the apical membrane of the ruminal mucosa. High concentrations of $\mathrm{K}$ increase this difference in potential, reducing the rate of diffusion of $\mathrm{Mg}$ from the rumen to the blood stream. The second mechanism is a carrier-mediated transport mechanism. However, there was no indication that $\mathrm{K}$ concentrations, ruminal or otherwise, remained increased in the KS cows at parturition. Urinary excretion of $\mathrm{K}$ and urinary $\mathrm{pH}$ converged to similar levels in the KS cows compared with the control cows from parturition onwards, so we discount the possibility that the hypomagnesemia was a consequence of a relatively immediate effect of high $\mathrm{K}$.

Nor was there any indication of an effect of treatment on feed intake at parturition. A depressed intake in the KS cows could have reduced their intake of $\mathrm{Mg}$, and daily intake of $\mathrm{Mg}$ is a key driver of $\mathrm{Mg}$ absorption. It was not possible to measure feed intake at parturition because by this time the cows had been returned to the commercial herd. Liveweight patterns and subsequent milk and milk component yields were the only indicators of feed intake perturbations, and no treatment effects on these were detected.

Alternatively, the carryover phenomenon may be an indication of damage or impairment to the second type of $\mathrm{Mg}$ transport, the carrier-mediated system (Martens and Blume, 1986; Schonewille et al., 1999; Martens and Schweigel, 2003). Constant exposure to a high K diet may have depressed the basal level of activity of the carrier-mediated system. We speculate that once the cows were returned to the lower $\mathrm{K}$ diet it took several weeks for the absorptive capacity of the ruminal epithelium to be restored. Presumably, the demand for $\mathrm{Mg}$ in late pregnancy was still low enough for the impaired 
system to cope, but the system became overloaded once the extra demands for lactogenesis and lactation were incurred. Magnesium would have been the most affected of all the bone minerals by a persistent perturbation to the ruminal mucosa. This is because in the adult the rumen remains the principal site of absorption for $\mathrm{Mg}$, whereas for $\mathrm{Ca}$ and $\mathrm{P}$, the principal site of absorption is the small intestine (Underwood and Suttle, 1999).

To conclude, a highly alkalinizing diet fed through late lactation and into the dry period conferred no detectable benefit to BMD and turnover. It is possible, however, that such a diet may impair the metabolism of $\mathrm{Mg}, \mathrm{P}$, and $\mathrm{Ca}$ at parturition, even if DCAD is reduced for at least $11 \mathrm{~d}$ prepartum and $\mathrm{Mg}$ intakes are apparently adequate. Where $\mathrm{K}$ intakes are high it may be necessary to provide additional $\mathrm{Mg}$ to any generalized strategy to reduce DCAD prepartum.

\section{ACKNOWLEDGMENTS}

Financial support from Canpotex Pty Ltd., Dairy Australia (Victoria, Australia), and the University of Sydney (New South Wales, Australia) is gratefully acknowledged, as is the generous assistance of Roger Giles (Elizabeth Macarthur Agricultural Institute, Menangle, New South Wales, Australia) with the scanning of the bone samples.

\section{REFERENCES}

Asai, H., N. Hayashi, N. Takai, Y. Yoshimura, Y. Nakamura, H. Yokota, and K. Kita. 2005. Estimation of daily urinary potassium excretion using urinary creatinine as an index substance in prepartum dairy cows. J. Anim. Sci. 76:51-54.

Beighle, D. E. 1999. The effect of gestation and lactation on bone calcium, phosphorus and magnesium in dairy cows. J. S. Afr. Vet. Assoc. 70:142-146.

Braithwaite, G. D. 1983. Calcium and phosphorus requirements of the ewe during pregnancy and lactation. 1. Calcium. Br. J. Nutr. 50:711-722.

Charbonneau, E., D. Pellerin, and G. R. Oetzel. 2006. Impact of lowering dietary cation-anion difference in nonlactating dairy cows: A meta-analysis. J. Dairy Sci. 89:537-548.

DeGaris, P. J., and I. J. Lean. 2008. Milk fever in dairy cows: A review of pathophysiology and control principles. Vet. J. 2008:58-69.

Edmonson, A. J., I. J. Lean, L. D. Weaver, T. Farver, and G. Webster. 1989. A body condition scoring chart for Holstein dairy cows. J. Dairy Sci 72:68-78.

Enevoldsen, C. 1993. Nutritional risk factors for milk fever in dairy cattle: Meta-analysis revisited. Acta Vet. Scand. Suppl. 89:131134 .

Fulkerson, W. J., J. S. Neal, C. F. Clark, A. Horadagoda, K. S. Nandra, and I. Barchiab. 2007. Nutritive value of forage species grown in the warm temperate climate of Australia for dairy cows: Grasses and legumes . Livest. Sci. 107:253-264.

Gibb, M. J., W. E. M. Ivings, S. Dhanoa, and J. D. Sutton. 1992 Changes in body components of autumn-calving Holstein-Friesian cows over the first 29 weeks of lactation. Anim. Prod. 55:339 360.

Goff, J. P. 2000. Pathophysiology of calcium and phosphorus disorders. Vet. Clin. North Am. Food Anim. Pract. 16:319-337.
Goff, J. P. 2006. Macromineral physiology and application to the feeding of the dairy cow for prevention of milk fever and other periparturient mineral disorders. Anim. Feed Sci. Technol. 126:237-257.

Goff, J. P. 2008. The monitoring, prevention, and treatment of milk fever and subclinical hypocalcemia in dairy cows. Vet. J. 176:5057.

Goff, J. P., and R. L. Horst. 1997. Effects of the addition of potassium or sodium, but not calcium, to prepartum rations on milk fever in dairy cows. J. Dairy Sci. 80:176-186.

Holmberg, T. B., G. R. Bergland, and B. Ahman. 1985. Long term studies on bone mineral changes during different lactations in Swedish dairy cattle. Acta Vet. Scand. 26:60-68.

Horst, R. L., J. P. Goff, T. A. Reinhardt, and D. R. Buxton. 1997. Strategies for preventing milk fever in dairy cattle. J. Dairy Sci. 80:1269-1280.

Hungerford, T. G. 1990. Hungerford's Diseases of Livestock. McGrawHill, New York, NY.

Jehle, S., A. Zanetti, J. Muser, H. N. Hulter, and R. Krapf. 2006. Partial neutralization of the acidogenic Western diet with potassium citrate increases bone mass in postmenopausal women with osteopenia. J. Am. Soc. Nephrol. 17:3213-3222.

Kronfeld, D. S., G. P. Mayer, and C. F. J. Ramburg, ed. 1976. Calcium homeostasis in cattle. Page 169 in Handbook of Endocrinology VII. The American Physiology Society, Bethesda, MD.

Lean, I. J., P. J. DeGaris, D. M. McNeil, and E. Block. 2006. Hypocalcemia in dairy cows: Meta-analysis and dietary cation anion difference theory revisited. J. Dairy Sci. 89:669-684.

Leonhard-Marek, S., and H. Martens. 1996. Effects of potassium on magnesium transport across rumen epithelium. Am. J. Physiol. 271:G1034-G1038.

Liesegang, A. 2003. Possibilities of monitoring bone metabolism in ruminants - An overview of the methods in use. Acta Vet. Scand. Suppl. 97:23-28.

Martens, H., and I. Blume. 1986. Effect of intraruminal sodium and potassium concentrations and of the transmural potential difference on magnesium absorption from the temporarily isolated rumen of sheep. Q. J. Exp. Physiol. 71:577-587.

Martens, H., and M. Schweigel. 2003. Influence of potassium on Mgand Ca-metabolism in cows: Effects and side-effects of research. Schweiz. Arch. Tierheilkd. 145:577-583.

McNeill, D. M., J. R. Roche, B. P. McLachlan, and C. R. Stockdale. 2002. Nutritional strategies for the prevention of hypocalcaemia at calving for dairy cows in pasture -based systems. Aust. J. Agric. Res. 53:755-770.

New, S. A. 2000. Impact of food clusters on bone. Pages 379-397 in Nutritional Aspects of Osteoporosis 2000. 4th International Symposium on Nutritional Aspects of Osteoporosis - Challenges of Modern Medicine. P. B. Dawson-Hughes and R. P. Heaney, ed. Ares-Serono Symposia Publications, Springer, Switzerland.

New, S. A., C. Bolton-Smith, D. A. Grubb, and D. M. Reid. 1997. Nutritional influences on bone mineral density: A cross sectional study in premenopausal women. Am. J. Clin. Nutr. 65:18311839.

New, S. A., S. P. Robins, M. K. Campbell, J. C. Martin, M. J. Garton, C. Bolton-Smith, D. A. Grubb, and D. M. Reid. 2000. Dietary influences on bone mass and bone metabolism: Further evidence of a positive link between fruit and vegetable consumption and bone health? Am. J. Clin. Nutr. 71:142-151.

Oetzel, G. R. 2000. Management of dry cows for the prevention of milk fever and mineral disorders. Vet. Clin. North Am. Food Anim. Pract. 16:369-386.

Ram, L., J. T. Schonewille, H. Martens, A. T. van Klooster, and A. C. Beynen. 1998. Magnesium absorption by wethers fed potassium bicarbonate in combination with different dietary magnesium concentrations. J. Dairy Sci. 81:2485-2492.

Reinhardt, T. A., R. L. Horst, and J. P. Goff. 1988. Calcium, phosphorus, and magnesium homeostasis in ruminants. Vet. Clin. North Am. Food Anim. Pract. 4:331-350.

Roche, J. R. 2003. The incidence and control of hypocalcaemia in pasture-based systems. Acta Vet. Scand. Suppl. 97:141-144. 
Roche, J. R., and D. P. Berry. 2006. Periparturient climatic, animal, and management factors influencing the incidence of milk fever in grazing systems. J. Dairy Sci. 89:2775-2783.

Roche, J. R., E. S. Kolver, A. Roberts, and J. Morton. 2003. Dietary potassium does not negatively affect blood calcium in periparturient cows fed pasture. Acta Vet. Scand. Suppl. 98:245. (Abstr.)

Sanchez, W. K., and D. K. Beede. 1996. Is there an optimal cation anion difference for lactation diets? Anim. Feed Sci. Technol. $59: 3-12$.

Schonewille, J. T., A. C. Beynen, A. T. Van't Klooster, H. Wouterse, and L. Ram. 1999. Dietary potassium bicarbonate and potassium citrate have a greater inhibitory effect than does potassium chloride on magnesium absorption in wethers. J. Nutr. 129:2043-2047.

Sebastian, A., S. T. Harris, J. H. Ottaway, K. M. Todd, and R. C. Morris. 1994. Improved mineral balance and skeletal metabolism in postmenopausal women treated with potassium bicarbonate. N. Engl. J. Med. 330:1776-1781.
Seifi, H. A., M. Mohri, and J. K. Zadeh. 2004. Use of pre-partum urine $\mathrm{pH}$ to predict the risk of milk fever in dairy cows. Vet. J. 167:281-285.

Tucker, K. L., M. T. Hannan, H. Chen, A. Cuppules, P. W. F. Wilson, and D. P. Kiel. 1999. Potassium and fruit and vegetables are associated with greater bone mineral density in elderly men and women. Am. J. Clin. Nutr. 69:727-736.

Underwood, E. J., and N. F. Suttle. 1999. Mineral Nutrition of Livestock. CAB International, Wallingford, UK.

van Mosel, M., A. T. van't Klooster, and A. Malestein. 1990. Effects of inadequate dietary intake of magnesium on osteogenesis in dairy cows during the dry period. Res. Vet. Sci. 48:280-287.

van Mosel, M., A. T. van't Klooster, and H. S. Wouterse. 1991. Effects of a deficient magnesium supply during the dry period on bone turnover of dairy cows at parturition. Vet. Q. 13:199-208.

Zetterholm, R. 1978. Bone mineral changes in growing pregnant and lactating cattle. Acta Vet. Scand. 19:18-29. 